\title{
Thermal conductivity of milk with different levels of moisture and fat: experimental measures and prediction models
}

\section{Condutividade térmica de leites com diferentes teores de umidade e gordura: medidas experimentais e modelos de predição}

\author{
Cristina Guimarães Pereira ${ }^{1 *}$; Jaime Vilela de Resende ${ }^{2}$; \\ Tales Márcio de Oliveira Giarola ${ }^{3}$; Sandra Maria $\mathrm{Pinto}^{2}$; Luiz Ronaldo de $\mathrm{Abreu}^{2}$
}

\begin{abstract}
Thermal conductivity is one of the most influential properties affecting the pasteurization of milk and is highly dependent on the milk composition and the temperature used in the process. The purpose of this work was to model the thermal conductivity of milk with a moisture content from 88.3 to $91.2 \%$ and fat content from 0 to $3.5 \%$ from 20 to $80^{\circ} \mathrm{C}$. For milk with a lower moisture percentage, the experimental conductivity ranged from 0.560 to $0.637 \mathrm{~W} \mathrm{~m}^{-1} \mathrm{~K}^{-1}$, and for those samples with a higher moisture percentage, conductivity ranged from 0.584 to $0.652 \mathrm{~W} \mathrm{~m}^{-1} \mathrm{~K}^{-1}$. Three theoretical predictive models, series, parallel and Maxwell-Eucken, which use food composition data, were tested, and polynomial functions were fit to model the behavior of this property as a function of moisture and fat content. The results showed that thermal conductivity values are linearly dependent on the moisture content and inversely dependent on the fat content. Among the models, the parallel model was the best fit to the experimental data with a maximum error of $2.7 \%$.
\end{abstract}

Key words: Thermal conductivity, structural models, hot wire probe, moisture, fat, milk

\section{Resumo}

A condutividade térmica é uma das propriedades mais influentes durante a pasteurização, sendo altamente dependente da composição do leite e da temperatura utilizada no processo. Este trabalho objetivou modelar a condutividade em uma faixa de temperatura de 20 a $80^{\circ} \mathrm{C}$ para leites com teores de umidade de 88,3 a $91,2 \%$ e teores de gordura entre 0 e 3,5\%. Para o leite com menor porcentagem de umidade, a condutividade variou de 0,560 a $0,637 \mathrm{~W} \mathrm{~m}^{-1} \mathrm{~K}^{-1}$ e para aquele com maior teor de umidade a condutividade esteve entre 0,584 a $0,652 \mathrm{~W} \mathrm{~m}^{-1} \mathrm{~K}^{-1}$. Três modelos teóricos de predição, série, paralelo e de Maxwell-Eucken, os quais utilizam dados da composição do alimento foram testados e funções polinomiais foram ajustadas para modelar o comportamento desta propriedade em função dos teores de umidade e gordura do leite. Os resultados mostraram que os valores da condutividade térmica são linearmente dependentes do teor de umidade e inversamente dependentes dos teores de gordura. Entre os modelos testados, o modelo Paralelo foi o que melhor se ajustou aos dados experimentais com erro máximo de 2,7\%.

Palavras-chave: Condutividade térmica, modelos estruturais, sonda com aquecimento, umidade, gordura, leite

\footnotetext{
${ }^{1}$ Discente de Doutorado, Dept ${ }^{\circ}$ de Ciência dos Alimentos, Universidade Federal de Lavras, UFLA, Lavras, MG. E-mail: crisgp13@ yahoo.com.br

2 Profs. do Dept ${ }^{\circ}$ de Ciência dos Alimentos, UFLA, Lavras, MG. E-mail: jvresende@dca.ufla.br; sandra@dca.ufla.br; lrabreu@ dca.ufla.br

${ }^{3}$ Discente de Doutorado/Técnico do Laboratório de Refrigeração de Alimentos do Dept ${ }^{\circ}$ de Ciência dos Alimentos, UFLA, Lavras, MG. E-mail: tgiarola@dca.ufla.br

* Author for correspondence
} 


\section{Introduction}

Milk is a food with high biological value that occupies a prominent place in human nutrition. Considered one of the principal nutrient and energy sources throughout the world, milk provides a wealth of nutrients for human growth. Its composition is essentially $87.0 \%$ moisture, $3.5 \%$ protein, $3.0 \%$ fat and $4.5 \%$ lactose. This composition is crucial to its nutritional quality and its suitability for processing and consumption (MINIM; COIMBRA; MINIM, 2002).

In thermal treatments such as pasteurization, concentration, drying and refrigeration, to which milk is often subjected, a specific understanding of the thermophysical properties involved is important. The thermal conductivity of a product is one of its most significant properties with regard to heat transfer (CARSON, 2006; SWEAT, 1986). This property is important to predicting and controlling the changes that occur in milk during processing. Additionally, accurate data are essential to estimating the processing time and the quantity of energy involved in thermal processes. Accurate data enable the determination of the correct size of the equipment used in both high- and low-temperature treatments (MURAMATSU; TAGAWA; KASAI, 2005). Collecting data on thermal conductivity is also important because, during the process of heating or refrigeration, changes may occur in the structural, physical and chemical properties of the product (SWEAT, 1986). Furthermore, thermal conductivity is highly dependent on the composition, fraction of ice and temperature of the food (MOHSENIN, 1980; PARK; ALONSO; NUNES, 1999). However, most of these data are presented in graphs or tables and are therefore difficult to use in calculations where thermophysical property values are required for different temperatures and compositions than those used experimentally. Thus, modeling equations to determine thermophysical properties using historical temperature and composition values for the material is fundamental (GAVRILA $\breve{A}$ et al., 2005).
The thermal conductivity of many foods has been measured, and the data can be found in Sweat (1986) and Ashrae (2002). However, due to the wide range of foods and compositions, it is impractical to obtain experimental data for all types of products (MURAMATSU; TAGAWA; KASAI, 2005). The major changes attributed to thermal conductivity resulting from the broad composition of the different materials and temperatures used in processing requires a more detailed understanding of this property (MOURA; VITALI; FRANÇA, 2001).

Studies of thermophysical properties using predictive models and new methods for determining these properties have been proposed. Of these, the hot wire probe method has emerged as the most commonly used method for food products (CARSON, 2006). To measure thermal conductivity by the transient-state method, a linear heat source is used to generate a constant flow of heat that is transmitted to the sample, which is initially in thermal equilibrium (DELGADO et al., 1997; PARK; ALONSO; NUNES, 1999; RENAUD et al., 1992).

Mathematical models have been developed that estimate the thermal conductivity of food products as a function of their basic chemical composition and moisture content. Food products consist of a mixture of pure substances such as carbohydrates, proteins, ash, fat, water and other components of known thermal conductivity. The combination of all of the components determines the thermal conductivity of the food product as a whole. The ratio of the effective thermal conductivity of a food product to the intrinsic conductivities of its components and the volume fractions of each component can be described by Eq. 1 .

$$
k_{\theta}=f\left(k_{1}, k_{2}, k_{3}, \ldots, X_{1}^{v}, X_{2}^{v}, X_{3}^{v}, \ldots\right)
$$

where $k_{\theta}$ is the effective thermal conductivity of the food; $k_{1}, k_{2}, k_{3}, \ldots$ are the intrinsic thermal conductivity values of the food components; and 
$X_{\mathbf{1}}^{v}, X_{\mathbf{2}}^{v}, X_{\mathbf{3}}^{v}, \ldots X_{\mathbf{1}}^{v}, X_{\mathbf{2}}^{v}, X_{\mathbf{3}}^{v}, \ldots$ are the volume fractions of each component (MIYAWAKI; PONGSAWATMANIT, 1994). The volume fraction of each component is determined using Eq. 2.

$$
X_{i}^{v}=\frac{\frac{x_{i}}{\rho_{i}}}{\sum \frac{x_{i}}{\rho_{i}}}
$$

where $x_{i}$ is the mass fraction, $\rho_{i}$ is the density of each component and $\sum X_{i}^{v}=\mathbf{1}$

Therefore, this study aimed to determine the experimental thermal conductivity of milk with different fat and moisture contents as a function of temperature and to subject these data to mathematical modeling. We present an evaluation of the series, parallel and Maxwell-Eucken structural prediction models and a comparison of the experimental results with predicted results.

\section{Materials and Methods}

In this study, six types of commercial milk with different levels of moisture and fat were used. Table 1 shows that the composition of the milks was between 0 and $3.5 \%$ fat and the moisture content was between 88.3 and $91.2 \%$.

Table 1. Milk composition.

\begin{tabular}{ccccccc}
\hline \multirow{2}{*}{ Milk } & \multicolumn{7}{c}{ Composition $(\%)$} \\
\cline { 2 - 7 } & Moisture & Protein & Fat & Carbohydrates & Fiber & Ashes \\
\hline 1 & 88.32 & 3.05 & 3.50 & 4.00 & 0 & 0.60 \\
2 & 88.41 & 3.10 & 3.00 & 4.65 & 0 & 0.61 \\
3 & 89.40 & 3.10 & 2.10 & 4.50 & 0 & 0.64 \\
4 & 89.97 & 3.00 & 1.00 & 4.50 & 0 & 0.65 \\
5 & 90.89 & 2.90 & 0.60 & 5.00 & 0 & 0.64 \\
6 & 91.21 & 3.00 & 0.00 & 5.00 & 0 & 0.69 \\
\hline
\end{tabular}

Source: Elaboration of the authors.

Thermal conductivity measurements were performed using the transient state method known as linear probe heating. This technique involves the application of heat to the material through a probe subjected to a constant heating rate provided by a current source. The probe consists of a hypodermic needle with an external diameter of $0.3 \mathrm{~mm}$ and a length of $70 \mathrm{~mm}$ as well as a nickel-chromium heating resistor that is $0.36 \mathrm{~m}$ long and $0.08 \mathrm{~mm}$ diameter with a resistance of $21.325 \Omega \mathrm{m}^{-1}$ and a T-type thermocouple (copper-constantan, AWG 30, Omega Engineering Inc. USA) in the exact center of the probe that was placed inside. Subsequently, all of the components were isolated using epoxy resin.
Heating power was applied to the linear resistance through the current source, and the increase in temperature was recorded by a signal conditioning system (National Instruments - SCXI model - Hungary) using Lab View 8.5 software (National Instruments, Ireland) with intervals of 1.0 second between each record. To stabilize and maintain the temperature of the samples (20 to $80^{\circ} \mathrm{C}$ ) an ultrathermostat bath was used (Nova Ética- 521/3DE model, Brazil).

The usual procedure for measuring thermal conductivity through the linear heating probe is based on applying a constant heat flow from the power source to the material, initially in balance, 
generating a temperature variation of $T_{\odot}$ to $T$ , at some point in the material (PARK; MURR; SALVADEGO, 1997). This temperature increase can be expressed by Eq. 3 .

$$
\mathbf{\Delta} T=T-T_{o}=\frac{q}{\mathbf{4} \pi k}\left[\ln \left(\frac{t}{t_{o}}\right)\right]
$$

To determine the heating power generated by the source (Eq. 4), the data from the resistance heating unit (nickel/chrome) inside the probe and the current supplied by the heating source were used.

$$
P=R \cdot i^{2}
$$

Using the power given by Eq. 4 and the length of the wire providing the electrical resistance, the power per linear meter supplied by the source is obtained by Eq. 5 .

$$
q=\frac{P}{\mathbf{L}}
$$

Eq. 3 illustrates the relationship between the thermal conductivity and the temperature difference $\left(T-T_{\emptyset}\right)$. The linear correlation of this difference and $\ln \left(\frac{t}{t_{o}}\right)$ is given by slope $(m)$, as calculated by Eq. 6 (BROCK et al., 2008).

$$
m=\frac{q}{4 \pi k}
$$

Thus, the thermal conductivity can be obtained from the linear coefficients of Eq. 6, as shown in Eq. 7.

$$
k=\frac{q}{\mathbf{4} \pi m}
$$

Prior to the determination of thermal conductivity, the probe was temperature calibrated, and a linear equation was obtained for its adjustment. In addition to calibration for temperature, the probe was calibrated using a solution of $40 \%$ sucrose (weight / volume in $\mathrm{H}_{2} \mathrm{O}$ ), which has a known thermal conductivity in the operating temperature range of the probe. With the calibration, it was possible to determine a factor $f$, as shown in Eq. 8. The experimental thermal conductivity of the milk was corrected using this factor (SARRIA; HONORIO, 2004).

$$
f=\frac{k_{\text {theoretical }}}{k_{\text {experimental }}}
$$

The value of $k_{\text {theoretical }}$ for the sucrose solution was obtained by Ashrae (2002) at temperatures of 0 , 20, 50 and $80^{\circ} \mathrm{C}$.

The effective thermal conductivity can be predicted from the intrinsic thermal conductivity combined with a template-appropriate heat transfer and the volumetric fraction of each component. The parallel, series and Maxwell-Eucken, and mathematical models that were used to predict the theoretical thermal conductivity of the food products (Table 2) and Eq. 9, 10 and 11, respectively (MIYAWAKI; PONGSAWATMANIT, 1994; RENAUD et al., 1992). 
Table 2. Structural models for determining thermal conductivity.

\begin{tabular}{|c|c|c|c|}
\hline Model & Schematic Diagram & Equation & \\
\hline Parallel & $\Longrightarrow$ & $k_{p a}=\sum X_{i}^{v} k_{i}$ & [9] \\
\hline Series & & $\frac{1}{k_{s e}}=\sum_{i=1}^{n} \frac{X_{i}^{v}}{k_{i}}$ & {$[10]$} \\
\hline $\begin{array}{l}\text { Maxwell- } \\
\text { Eucken }\end{array}$ & 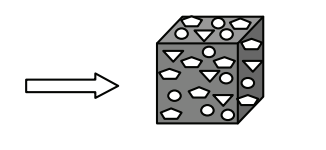 & $k_{m e}=k_{q}\left\{\frac{k_{d}+2 k_{c}-2 X_{d}^{v}\left(k_{c}-k_{d}\right)}{k_{d}+2 k_{d}+X v\left(k_{\varepsilon}-k_{d}\right)}\right\}$ & [11] \\
\hline
\end{tabular}

Source: (MIYAWAKI; PONGSAWATMANIT, 1994).

In the equations in Table $2, k_{p a}$ is the parallel thermal conductivity $\left(\mathrm{W} \mathrm{m}^{-1} \mathrm{~K}^{-1}\right), k_{s e}$ is the series thermal conductivity $\left(\mathrm{W} \mathrm{m}^{-1} \mathrm{~K}^{-1}\right), k_{m e}$ is MaxwellEucken thermal conductivity $\left(\mathrm{W} \mathrm{m}^{-1} \mathrm{~K}^{-1}\right), i$ indicates a pure component (protein, ash, fiber, carbohydrate, fat and water), $n$ is the number of components, $c$ indicates the continuous phase and $d$ indicates the dispersed phase.
In the parallel model, the thermal conductivity is calculated by summing the product of the thermal conductivity and the volumetric fraction of each component. In the series model, the phases are in series, or perpendicular to the flow of heat, which causes a high resistance to its passage through the sample. The Maxwell-Eucken model is the result of a combination of the models in series and in parallel, so the resistance values that it calculates are intermediate between the values calculated by the other models (MIYAWAKI; PONGSAWATMANIT, 1994). Table 3 shows the equations for determining the density and thermal conductivity of the pure components. 
Table 3. Models of the thermal conductivity and density of food components $\left(-40^{\circ} \mathrm{C} \leq \mathrm{T} \leq 150^{\circ} \mathrm{C}\right)$.

\begin{tabular}{|c|c|c|}
\hline Components & Thermal conductivity $\left(\mathrm{W} \mathrm{m}^{-1} \mathrm{~K}^{-1}\right)$ & \\
\hline Protein & $k=1.7881 \times 10^{-1}+1.1958 \times 10^{-3} T-2.7178 \times 10^{-6} T^{2}$ & {$[12]$} \\
\hline Fat & $k=1.8071 \times 10^{-1}-2.7604 \times 10^{-3} T-1.7749 \times 10^{-7} T^{2}$ & {$[13]$} \\
\hline Carbohydrate & $k=2.0141 \times 10^{-1}+1.3874 \times 10^{-3} \mathrm{~T}-4.3312 \times 10^{-6} \mathrm{~T}^{2}$ & {$[14]$} \\
\hline Fiber & $k=1.8331 \times 10^{-1}+1.2497 \times 10^{-3} \mathrm{~T}-3.1683 \times 10^{-6} \mathrm{~T}^{\mathbf{2}}$ & {$[15]$} \\
\hline Ashes & $k=3.2962 \times 10^{-1}+1.4011 \times 10^{-3} \mathrm{~T}-2.9069 \times 10^{-6} \mathrm{~T}^{2}$ & {$[16]$} \\
\hline \multirow[t]{2}{*}{ Water } & $k=5.7109 \times 10^{-1}+1.7625 \times 10^{-3} \mathrm{~T}-6.7036 \times 10^{-6} \mathrm{~T}^{\mathbf{2}}$ & {$[17]$} \\
\hline & \multicolumn{2}{|l|}{ Density $\left(\mathrm{kg} \mathrm{m}^{-3}\right)$} \\
\hline Protein & $\rho=1.3299 \times 10^{3}-5.1840 \times 10^{-1} \mathrm{~T}$ & {$[18]$} \\
\hline Fat & $\rho=9.2559 \times 10^{2}-4.1757 \times 10^{-1} \mathrm{~T}$ & [19] \\
\hline Carbohydrate & $\rho=1.5991 \times 10^{3}-3.1046 \times 10^{-1} \mathrm{~T}$ & {$[20]$} \\
\hline Fiber & $\rho=1.3115 \times 10^{3}-3.6589 \times 10^{-1} \mathrm{~T}$ & {$[21]$} \\
\hline Ashes & $\rho=2.4238 \times 10^{3}-2.8063 \times 10^{-1} \mathrm{~T}$ & {$[22]$} \\
\hline Water & $\rho=9.9718 \times 10^{2}+3.1439 \times 10^{-3} T-3.7574 \times 10^{-3} T^{2}$ & [23] \\
\hline
\end{tabular}

Source: (ASHRAE, 2002).

The effective thermal conductivity of milk was compared to the theoretical values obtained from the mathematical models. The percentage error was calculated using Eq. 24.

$\%$ Error $=I\left(\left(k_{1} \exp -k_{1}\right.\right.$ theor $\left.)\right) / k_{1} \exp \mid 100$

\section{Results and Discussion}

The correlation between the average temperature measured experimentally using the thermocouple and the temperature of the thermometer was obtained by an adjustment equation with a correlation coefficient $\left(\mathrm{R}^{2}\right)$ of 0.999 , as shown in
Figure 1. Table 4 shows the experimental results, theoretical results and correction factor obtained at each temperature. The factor $f$ of 1.92 was used to correct the experimental thermal conductivity of the milk analyzed.

Figure 2 shows the experimental results for the temperature response versus time due to the heat provided by the probe inserted into the center of the sample with the temperature stabilized at $40^{\circ} \mathrm{C}$. Figure 3 shows the experimental results for the temperature increase versus the logarithm of the time used to obtain the parameter $m$ and the conductivity as described in Eq. 6 and 7. 
Figure 1. Calibration of the probe with respect to the temperature profiles.

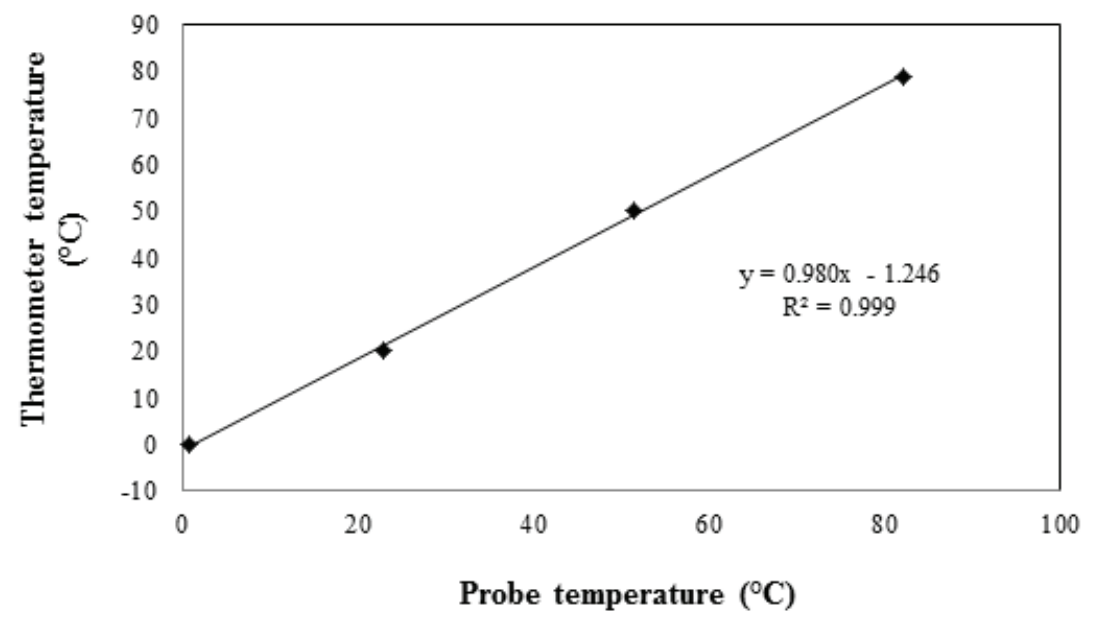

Source: Elaboration of the authors.

Table 4. Experimental thermal conductivity and theoretical values obtained by Ashrae (2002) for $40 \%$ sucrose solution.

\begin{tabular}{ccccc}
\hline \multirow{2}{*}{ Temperature $\left({ }^{\circ} \mathrm{C}\right)$} & \multirow{2}{*}{ Slope $(m)$} & \multicolumn{2}{c}{ Thermal conductivity $\left(\mathrm{W} \mathrm{m}^{-1} \mathrm{~K}^{-1}\right)$} & \multirow{2}{*}{ Factor $f$} \\
\cline { 3 - 4 } & 3.840 & Experimental & Theoretical & 2.046 \\
20 & 3.519 & 0.217 & 0.443 & 1.989 \\
50 & 3.303 & 0.236 & 0.470 & 1.994 \\
80 & 2.599 & 0.252 & 0.502 & 1.641 \\
\hline \multicolumn{4}{r}{} \\
\hline
\end{tabular}

Source: Elaboration of the authors.

Figure 2. Experimental results of temperature versus time produced by a hot wire probe while heating the milk sample that was initially stabilized at $40{ }^{\circ} \mathrm{C}$.

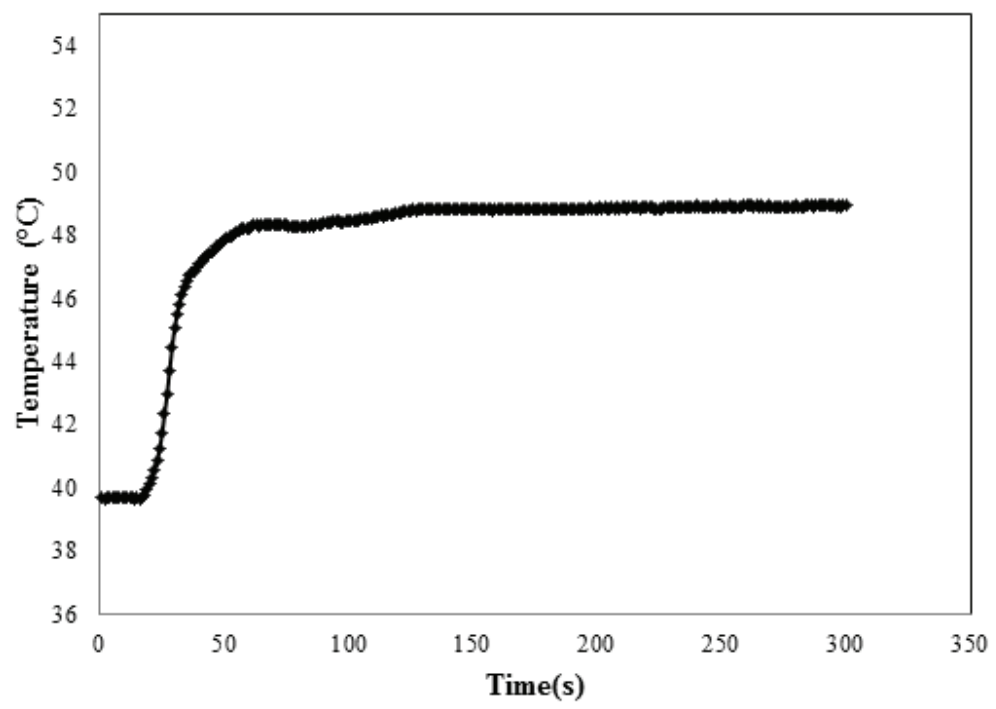

Source: Elaboration of the authors. 
Figure 3. Linearization of the temperature increase data for the sample initially stabilized at $40^{\circ} \mathrm{C}$.

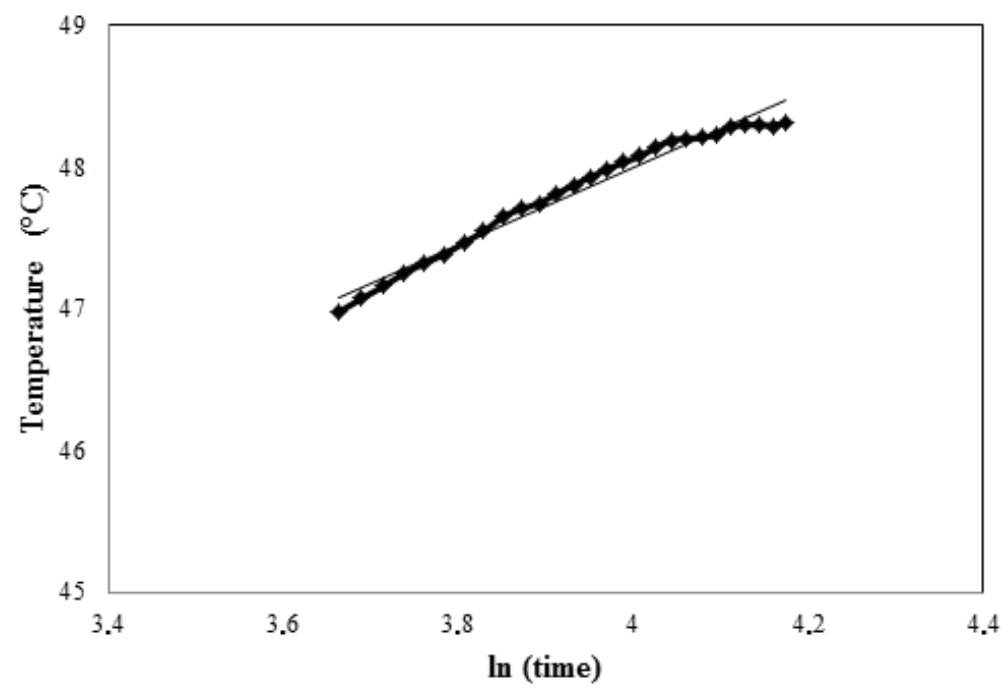

Source: Elaboration of the authors.

The evaluation of the thermal conductivity of milk with a moisture content of 88.3 to $91.2 \%$ and a fat content ranging from 0 to $3.5 \%$ in the temperature range of 20 to $80^{\circ} \mathrm{C}$ revealed that this property varied linearly with temperature. Figure 4 shows that the thermal conductivity of milk with $0.6 \%$ fat can be determined as a function of temperature with a regression coefficient $\mathrm{R}^{2}=0.995$ using Eq. 25 .

Figure 4. Thermal conductivity versus temperature for milk with $0.6 \%$ fat.

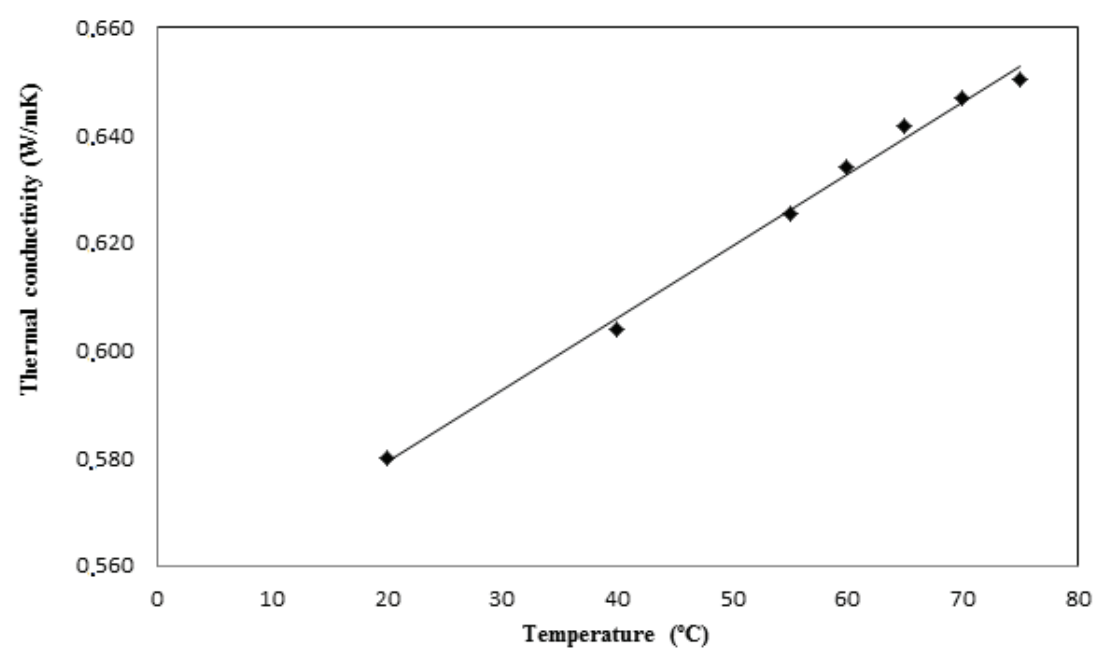

Source: Elaboration of the authors. 


$$
k(T)=0.0013 T+0.5526
$$

It was also observed that the relationship between the thermal conductivity of the milk at different fat concentrations and temperature is linear, as shown by Eq. 26.

$$
k(T)=A(T)+B
$$

Figure 5 shows the change in the thermal conductivity of milk with different fat contents over the same temperature range. An analysis of Figure 5 shows that milk with high fat content presents smaller thermal conductivity values for the same temperature range. This increase in conductivity with reduced fat content is related to the amount of water present. A lower fat content corresponds to a higher percentage of moisture, and water is the food component that contributes the most to the increase in conductivity (ASHRAE, 2002). Using the equations (Table 3 ), it can be observed that at $30^{\circ} \mathrm{C}$, the protein, fat, carbohydrate, fiber and ash components have intrinsic conductivities of 0.212 , $0.098,0.239,0.218,0.369 \mathrm{~W} \mathrm{~m}^{-1} \mathrm{~K}^{-1}$, respectively and that the intrinsic conductivity of water is 0.618 $\mathrm{W} \mathrm{m} \mathrm{m}^{-1} \mathrm{~K}^{-1}$.

Table 5 shows the coefficients A and B of the equation obtained for milk with different fat contents. The parameters A and B were subjected to regression analysis, which determined the linear equations that depend on the fat content, shown in Eq. 27 and 28.

Table 5. Parameters A, B and the regression coefficient obtained for milk with different fat contents

\begin{tabular}{cccc}
\hline \multirow{2}{*}{ Fat (\%) } & \multicolumn{2}{c}{ Coefficients of the equation } & \multirow{2}{*}{$\mathrm{R}^{2}$} \\
\cline { 2 - 3 } & $\mathrm{A}$ & $\mathrm{B}$ & 0.9857 \\
3.5 & 0.0013 & 0.5319 & 0.9946 \\
2.0 & 0.0013 & 0.5376 & 0.9929 \\
1.1 & 0.0013 & 0.5440 & 0.9600 \\
0.6 & 0.0013 & 0.5525 & 0.9950 \\
0.0 & 0.0013 & 0.5526 & 0.9582 \\
\hline
\end{tabular}

Source: Elaboration of the authors.

Figure 5. Variation in thermal conductivity for milk with different fat contents analyzed at different temperatures.

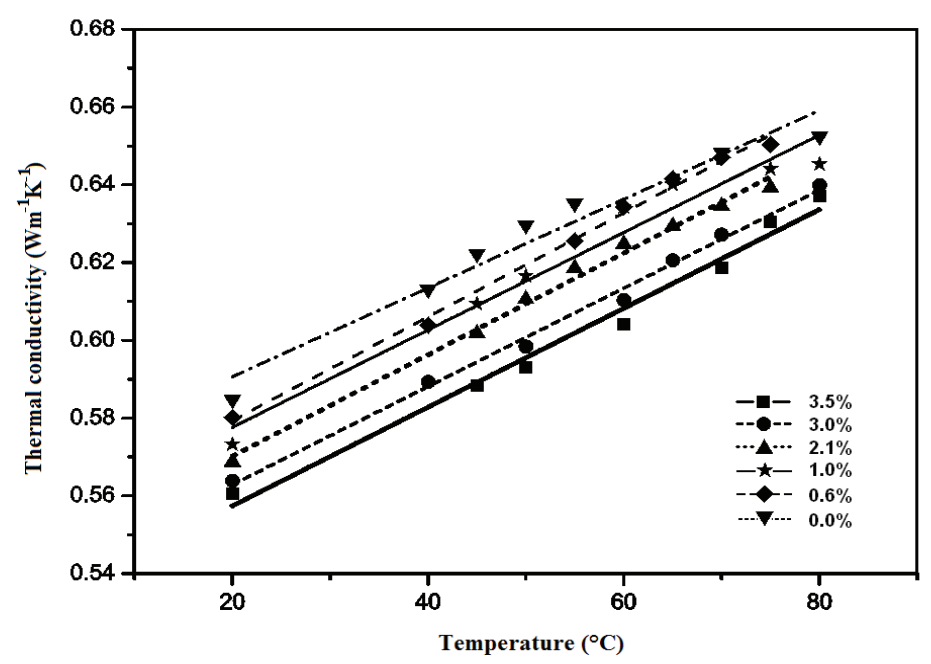

Source: Elaboration of the authors. 


$$
\begin{gathered}
A=3.5124 \times 10^{-5} F+1.207 \times 10^{-3} \\
B=-8.8811 \times 10^{-3} F+5.6283 \times 10^{-1}
\end{gathered}
$$

where $F$ is the fat content in milk.

Substituting Eq. 27 and 28 into Eq. 26, a dualparameter equation was obtained that relates the thermal conductivity of milk to different fat contents at different temperatures, as shown in Eq. 29.

$$
\begin{gathered}
K(T, F)=\left(3.5124 \times 10^{-5} G+1.207 \times 10^{-3}\right) T- \\
-8.8811 \times 10^{-3} F+5.6283 \times 10^{-1}
\end{gathered}
$$

Eq. 29 confirms that milks with higher fat percentages have lower conductivity because of the negative influence of the fat content on the thermal conductivity; the negative term related to the fat variable is greater than the positive term. In terms of moisture, the thermal conductivity of milk was evaluated in the same way. The coefficients $\mathrm{A}$ and B (Table 6) were subjected to regression analysis to correlate them with different moisture percentages.

Table 6. Parameters A, B and the regression coefficient obtained for milks with different moisture contents.

\begin{tabular}{cccc}
\hline \multirow{2}{*}{ Moisture (\%) } & \multicolumn{2}{c}{ Coefficients of the equation } & \multirow{2}{*}{$\mathrm{R}^{2}$} \\
\cline { 2 - 3 } & $\mathrm{A}$ & $\mathrm{B}$ & 0.9857 \\
88.323 & 0.0013 & 0.5319 & 0.9946 \\
88.419 & 0.0013 & 0.5376 & 0.9929 \\
89.403 & 0.0013 & 0.5440 & 0.9600 \\
89.970 & 0.0013 & 0.5525 & 0.9950 \\
90.896 & 0.0013 & 0.5526 & 0.9582 \\
91.211 & 0.0011 & 0.5678 & \\
\hline
\end{tabular}

Source: Elaboration of the authors.

The parameters A and B obtained by Eq. 30 and 31 were combined with Eq. 26, resulting in Eq. 32, which relates the thermal conductivity of milk with different amounts of moisture at different processing temperatures.

$$
\begin{aligned}
& A=-4.0677 \times 10^{-5} M+4.9155 \times 10^{-3} \\
& B=9.8918 \times 10^{-3} M-3.3960 \times 10^{-1}
\end{aligned}
$$

where $M$ is the moisture content.

$$
\begin{aligned}
& k(T, M)=\left(-4.0677 \times 10^{-5} M+4.9155 \times 10^{-3}\right) T+ \\
& \quad+9.8918 \times 10^{-3} M-3.3960 \times 10^{-1} \mid
\end{aligned}
$$

Eq. 32 indicates that thermal conductivity increases as the milk moisture content increases. Although the first term, which related to variable moisture, is negative, it is less than the following term, which explains why milk with higher water content presents higher conductivity at the same temperature. Minim, Coimbra and Minim (2002) assessed some of the thermophysical properties of whole milk, skim milk and part skim milk and also found a linear relationship between all of the properties studied. They found that the water content was the factor that had the greatest influence on the properties, while the fat content had less influence. Tavman and Tavman (1999) evaluated the thermal conductivity of eleven types of cheese, four types of yogurt and a sample of butter using the hot wire method and evaluated the influence of fat, protein and water on the thermal conductivity of these products. The measured values were linearly dependent on the water content and inversely dependent on the fat and protein contents of the various dairy products. 
In addition to experimental measurements, the thermal conductivity of milk was evaluated using the series, parallel and Maxwell-Eucken models found in the literature. In these models, the carbohydrate, protein, ash, fat, water and other components, which all have an intrinsic conductivity, contribute to the thermal conductivity of the food as a whole (MIYAWAKI; PONGSAWATMANIT, 1994).

Figure 6 shows a comparison of the thermal conductivity values obtained experimentally and those obtained by the mathematical models for milk with $89.4 \%$ moisture and $2.1 \%$ fat. Figure 6 shows that the parallel model provided the best fit for the experimental data when compared to the other two models (series and Maxwell-Eucken). Table 7 shows a comparison between the experimental results and those predicted by the models for a milk sample containing $89.4 \%$ moisture and $2.1 \%$ fat and the errors associated with each temperature studied. The parallel model best fit the experimental data for all of the milks analyzed, yielding a maximum error of $2.7 \%$ for milk with $88.4 \%$ moisture and $3 \%$ fat. Although the errors found between the thermal conductivity values obtained experimentally and those obtained by the mathematical parallel model were small, it is important an adjustment of a specific model for determining the thermal conductivity of the milk. According Park, Alonso and Nunes (1999) the resultant effect of temperature on the thermal conductivity is not easily established by use of only basic knowledge of the composition of the food. This is because any factors as the density, the arrangement of pores, ice fraction and arrangement of fibers affects heat flow through the material.

Figure 6. Thermal conductivity of a milk sample with $89.4 \%$ moisture and $2.1 \%$ fat at temperatures of 20 to $80^{\circ} \mathrm{C}$ as predicted by the parallel, series and Maxwell-Eucken theoretical models compared with the results obtained experimentally.

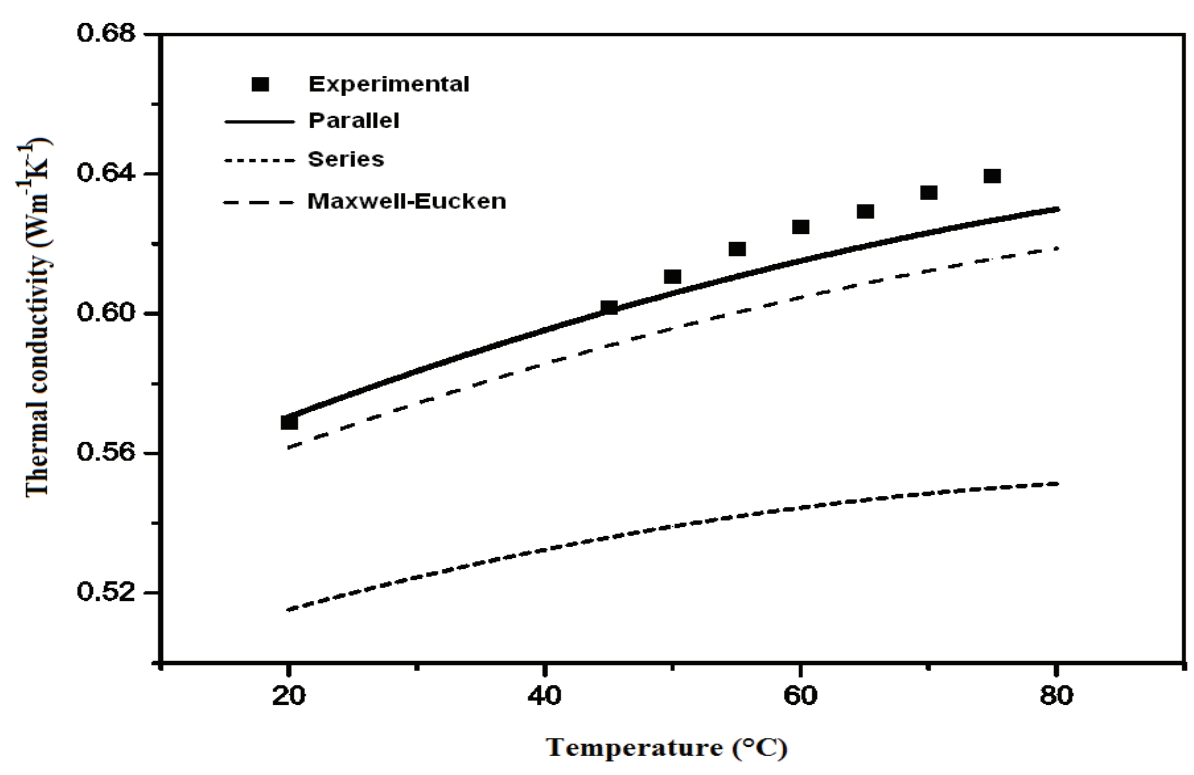

Source: Elaboration of the authors. 
Table 7. Comparison between the experimental and theoretical results for the thermal conductivity of milk with $89.4 \%$ moisture and $2.1 \%$ fat.

\begin{tabular}{cccccccc}
\hline $\begin{array}{c}\text { Temperature } \\
\left({ }^{\circ} \mathrm{C}\right)\end{array}$ & $\begin{array}{c}\mathrm{k}_{\text {exp }} \\
\left(\mathrm{W} \mathrm{m}^{-1} \mathrm{~K}^{-1}\right)\end{array}$ & $\begin{array}{c}\mathrm{k}_{\text {parallel }} \\
\left(\mathrm{W} \mathrm{m}^{-1} \mathrm{~K}^{-1}\right)\end{array}$ & $\begin{array}{c}\text { Error } \\
(\%)\end{array}$ & $\begin{array}{c}\mathrm{k}_{\text {series }} \\
\left(\mathrm{W} \mathrm{m}^{-1} \mathrm{~K}^{-1}\right)\end{array}$ & $\begin{array}{c}\text { Error } \\
(\%)\end{array}$ & $\begin{array}{c}\mathrm{k}_{\text {Maxwell-Eucken }} \\
\left(\mathrm{W} \mathrm{m}^{-1} \mathrm{~K}^{-1}\right)\end{array}$ & Error (\%) \\
\hline 20 & 0.569 & 0.570 & 0.302 & 0.515 & 9.391 & 0.562 & 1.232 \\
45 & 0.602 & 0.601 & 0.181 & 0.536 & 10.945 & 0.591 & 1.816 \\
50 & 0.611 & 0.606 & 0.786 & 0.539 & 11.713 & 0.596 & 2.431 \\
55 & 0.619 & 0.611 & 1.282 & 0.542 & 12.386 & 0.600 & 2.940 \\
60 & 0.625 & 0.615 & 1.549 & 0.544 & 12.856 & 0.605 & 3.222 \\
65 & 0.629 & 0.619 & 1.600 & 0.547 & 13.139 & 0.609 & 3.293 \\
70 & 0.635 & 0.623 & 1.804 & 0.549 & 13.561 & 0.612 & 3.514 \\
75 & 0.639 & 0.627 & 1.973 & 0.550 & 13.955 & 0.616 & 3.699 \\
\hline
\end{tabular}

Source: Elaboration of the authors.

\section{Conclusions}

The models used to determine the thermal conductivity of milk showed similar behavior to the experimentally obtained data, with increases in conductivity as a function of temperature increases. It was observed that conductivity is linearly dependent on the water content of the milk and inversely dependent on the fat content.

However in none of the tested models there was a total adjustment of the experimental data. Parallel model resulted in maximum errors of $2.7 \%$, compared to the Maxwell-Eucken model, which resulted in maximum errors of $3.7 \%$.

The equations obtained using the experimental data to evaluate the thermal conductivity of milk in the temperature range $20-80^{\circ} \mathrm{C}$ are simple polynomial functions that allow direct calculation of this property using only the knowledge of the milk's composition in terms of moisture and fat content and the temperature history obtained during thermal processing. These equations provide data that can be used to optimize the duration of industrial processes and facilitate the design of the equipment used in processing. These equations allow the simulation of thermal conductivity without the need to measure it experimentally.

\section{Acknowledgments}

The authors wish to thank the Fundação de Amparo à Pesquisa do Estado de Minas Gerais (FAPEMIG- Brazil), Conselho Nacional de Desenvolvimento Científico e Tecnológico (CNPq - Brazil) and Coordenação de Aperfeiçoamento de Pessoal de Nível Superior (CAPES - Brazil) for financial support for this research.

\section{Nomenclature}

A Coefficient of Eq. 26

$B \quad$ Coefficient of Eq. 26

F Fat (\%)

M Moisture (\%)

$T \quad$ Temperature $\quad\left({ }^{\circ} \mathrm{C}\right)$

X Volumetric fraction

$x \quad$ Mass fraction

Correction factor

$k \quad$ Thermal conductivity $\quad\left(\mathrm{W} \mathrm{m}^{-1} \mathrm{~K}^{-1}\right)$

$m$ Slope -

$q \quad$ Flow heat $\quad\left(\mathrm{W} \mathrm{m}^{-1}\right)$

$\rho \quad$ Density $\quad\left(\mathrm{kg} \mathrm{m}^{-3}\right)$ 


\begin{tabular}{ll}
\multicolumn{2}{l}{ Subscriptions } \\
$c$ & Continuous phase \\
$d$ & Disperse phase \\
exp & Experimental \\
$i$ & Pure component \\
$m e$ & Maxwell-Eucken \\
pa & Parallel \\
se & Series \\
theor & Theoretical
\end{tabular}

\section{References}

ASHRAE. Handbook refrigeration. American society of heating, refrigeration and air-conditioning engineers. Atlanta, GA, 2002.

BROCK, J.; NOGUEIRA, M. R.; ZAKRZEVSKI, C.; CORAZZA, F. C.; CORAZZA, M. L.; OLIVEIRA, J. V. Determinação experimental da viscosidade e condutividade térmica de óleos vegetais. Ciência e Tecnologia de Alimentos, Campinas, v. 28, n. 3, p. 564570, 2008.

CARSON, J. K. Review of effective thermal conductivity models for food. International Journal of Refrigeration, Surrey, v. 29, n. 6, p. 958-967, 2006.

DElGADO, A. E.; GALlO, A.; PIANTE, D.; RUBIOLO, A. Thermal conductivity of unfrozen and frozen Strawberry and Spinach. Journal of Food Engineering, Essex, v. 31, n. 2, p. 137-146, 1997.

GAVRILĂ, L.; FÎNARU, A.; ISTRATI, L.; SIMION, A. I.; CIOCAN, M. E. Influence of temperature, fat and water content on the thermal conductivity of some dairy products. J. Agroaliment. Processes Technol., Timisoara, v. 11, n. 1, p. $205-210,2005$.

MINIM, L. A.; COIMBRA, J. S. R.; MINIM, V. P. R. Influence of temperature and water and fat contents on the thermophysical properties of milk. Journal of Chemical \& Engineering. Data, Washington, v. 47, n. 6, p. 1488-1491, 2002.
MIYAWAKI,O.;PONGSAWATMANIT,R. Mathematical analysis of the effective thermal conductivity of food materials in the frozen state. Bioscience, Biotechnology, and Biochemistry, Tokyo, v. 58, n. 7, p. 1222-1225, 1994.

MOHSENIN, N. N. Thermal properties of foods and agricultural materials. London: Gordon and Breach, 1980.

MOURA, S. C. S. R.; VITALI, A. A.; FRANÇA, V. C. L. Propriedades termofísicas de soluções modelo similares a creme de leite. Ciência e Tecnologia de Alimentos, Campinas, v. 21, n. 2, p. 209-215, 2001.

MURAMATSU, Y; TAGAWA, A.; KASAI, T. Thermal conductivity of several liquid foods. Food Science and Technology Research, Tsukuba, v. 11, n. 3, p. 288-294, 2005.

PARK, K. J.; ALONSO, L. F.; NUNES, A. S. Determinação experimental da condutividade e difusividade de grãos em regime permanente. Ciência e Tecnologia de Alimentos, Campinas, v. 19, n. 2, p. 264269, 1999.

PARK, K. J.; MURR, F. E. X.; SALVADEGO, M. Medição da condutividade térmica de milho triturado pelo método da sonda. Ciência e Tecnologia de Alimentos, Campinas, v. 17 , n. 3, p. 242-247, 1997.

RENAUD, T.; BRIERY, P.; ANDRIEU, J.; LAURENT, M. Thermal Properties of food materials in the frozen state. Journal of Food Engineering, Essex, v. 15, n. 2, p. 83-97, 1992.

SARRIA, S. D.; HONORIO, S. L. Condutividade e difusividade térmica do figo (Ficuscarica L.) Roxo de Valinhos. Engenharia Agrícola, Jaboticabal, v. 24, n. 1, p. 185-194, 2004.

SWEAT, V. E. Thermal properties of foods. New York: Marcel Dekker, 1986.

TAVMAN, I. H.; TAVMAN, S. Measurement of thermal conductivity of dairy products. Journal of Food Engineering, Essex, v. 41, n. 2, p. 109-114, 1999. 
